\section{AQUIFER DETECTION USING 2-D RESISTIVITY METHOD AND POROSITY CALCULATION}

\author{
Umi Maslinda Anuar*, M. M. Nordiana \\ Geophysics Section, School of Physics, Universiti Sains Malaysia, \\ 11800 Minden, Pulau Pinang, Malaysia
}

Article history

Received

10 October 2017

Received in revised form

14 May 2018

Accepted

15 June 2018

Published online

5 October 2018

*Corresponding author
mmnordiana@usm.my

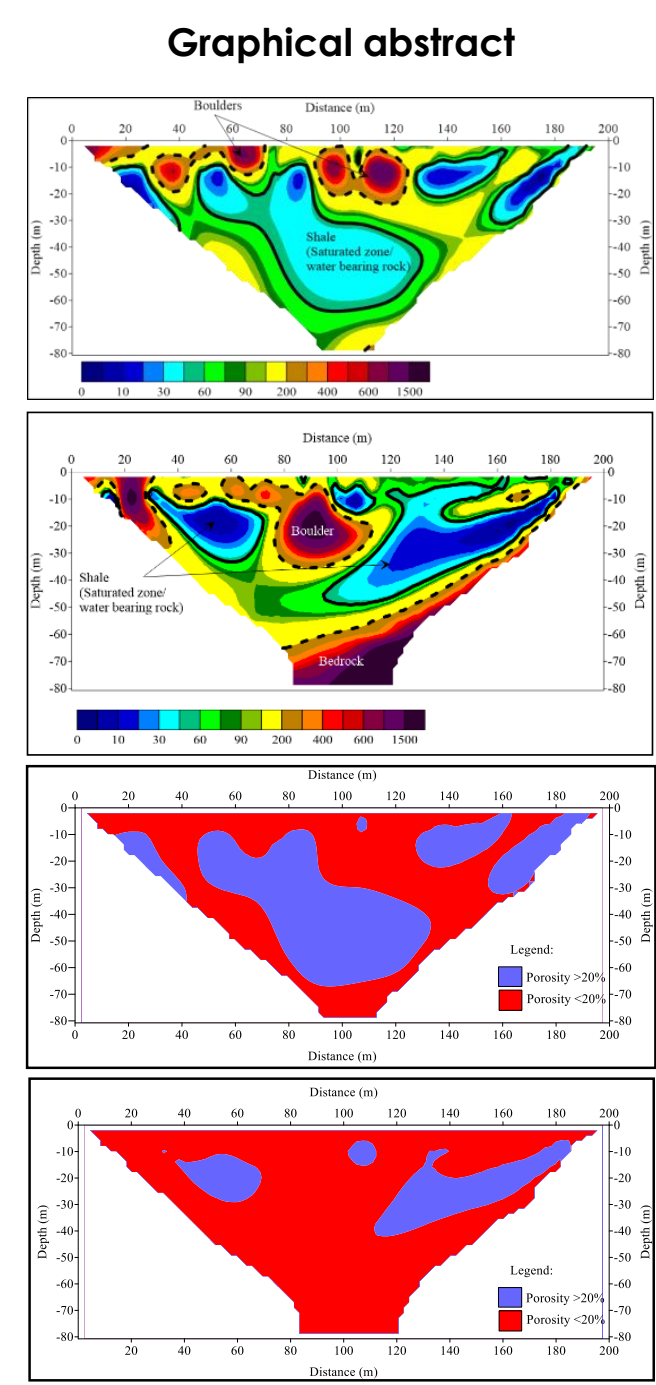

\begin{abstract}
2-D resistivity method has been widely used for aquifer detection, where aquifers are usually made of porous rocks. The aim of this study is to detect the aquifer using 2-D resistivity method and porosity calculation from Archie's Law. The porosity of the subsurface materials can be known and the porous materials can be easily detected. This study was done at two different locations which are in Selangor and Kelantan. Two lines of 2-D resistivity survey were conducted at each location. The results were correlated with borehole records. Only one borehole was executed at each location near to the 2-D resistivity lines. The saturated zones (1-100 $\Omega \mathrm{m}$ ) that found from the 2-D resistivity results were suspected to be an aquifer, and the zones were validated by the borehole records. Lastly, the porosity was calculated for all $2-D$ resistivity lines and an imaging was created for each line. A productive sedimentary aquifer should have porosity percentage of $>20 \%$ and the saturated zone at both study area have porosity percentage of $>20 \%$ as expected.
\end{abstract}

Keywords: 2-D resistivity, aquifer, saturated zone, porosity, imaging

\begin{abstract}
Abstrak
Kaedah keberintangan 2-D telah meluas digunakan untuk mengesan akuifer dan akuifer biasanya terjadi dalam lingkungan batu poros. Oleh itu, tujuan kajian ini adalah untuk mengesan akuifer menggunakan kaedah keberintangan 2-D dan hitungan keporosan daripada hukum Archie. Keporosan bahan-bahan bawah permukaan boleh diketahui dan bahanbahan poros akan mudah dikesan. Kajian ini telah dijalankan di dua lokasi yang berbeza iaitu di Selangor dan Kelantan. Dua garisan keberintangan 2 D telah dikendalikan di setiap lokasi. Hasil kajian akan dikolerasi dengan rekod lubang bor. Hanya satu lubang bor telah dilaksanakan di setiap lokasi berhampiran dengan garisan keberintangan 2-D. Zon tepu (1-100 $\Omega \mathrm{m}$ ) yang dikesan daripada hasil kajian keberintangan 2-D dipercayai adalah akuifer. Zon tepu kemudian dibuktikan dengan rekod lubang bor adalah akuifer. Akhirnya, keporosan telah dihitung untuk semua garisan keberintangan 2-D dan pengimejan telah direka untuk setiap garisan. Akuifer sedimen yang produktif mempunyai peratusan keporosan melebihi $20 \%$ dan zon tepu di kedua-dua kawasan kajian ini mempunyai peratusan keporosan melebihi $20 \%$ seperti yang dijangkakan.
\end{abstract}

Kata Kunci: Keberintangan 2-D, akuifer, zon tepu, keporosan, imejan

(C) 2018 Penerbit UTM Press. All rights reserved 


\subsection{INTRODUCTION}

Geophysical methods can be applied for both groundwater resource mapping and water quality evaluations. Near-surface geophysics have been extensively used in groundwater investigations. The application of near surface geophysics for groundwater include the mapping the depth and thickness of aquifers, mapping aquitards or confining units, locating preferential fluid migration paths such as fractures, fault zones and mapping contamination to the groundwater such as saltwater intrusion. Reynolds covered in detail about groundwater and near surface investigations [1]. Many geophysical techniques have been applied to groundwater investigations. The potential field methods, gravity and magnetics have been used to map regional aquifers and large-scale basin features. Seismic methods have been used to delineate bedrock aquifers and fractures systems. Electrical and electromagnetic methods are applicable for groundwater studies as many geological formation properties are related to hydrogeology such as the porosity and permeability of rocks that can be correlated with electrical conductivity signatures.

Although many geophysical techniques could be employed for groundwater characterization, the electrical and electromagnetics methods are better in directly mapping and monitoring contaminated and clean groundwater. The knowledge of the aquifer characteristics is important in determining aquifer potential. The 2-D resistivity method is an electrical method for subsurface study and has the capability in exploring and identifying aquifer characteristics [2]. It measures the resistivity distribution of the subsurface. Different materials in the subsurface have different resistivity values that can help in detecting the groundwater. It is a non-destructive and cost-effective method for locating the aquifer. This method is commonly being used to detect aquifer, as it can penetrate deeper. The 2-D resistivity method is also applicable in the identification of subsurface formations, groundwater zones, groundwater salinity and anthropogenic contamination [3].

The 2-D resistivity method is related to various geological parameters such as the mineral and fluid content, porosity and degree of water saturation in the rock. It also provides accurate depth information, which is important in locating aquifer. Since the water table in Malaysia is generally shallow, the fractures are commonly filled with groundwater. The greater the fracturing, the lower the resistivity value of the rock [4]. The resistivity value of water is low due to its high conductivity.

This study does not only adopt 2-D resistivity method in locating the aquifer, it also utilized the resistivity value to calculate the porosity percentage of the subsurface using the Archie's Law.

\subsection{2-D Resistivity Theory}

2-D resistivity method measures the potential difference produced by current injected into the ground. This current is injected via two current electrodes, and the potential difference is measured at another two potential electrodes [5]. It is the measurement of how strong a material resists the flow of electric current [6]. Different materials of the subsurface may have different resistivity values. Thus, the resistivity distribution of the subsurface can be map through this method.

\subsection{Archie's Law}

The porosity of the subsurface's materials may affect the resistivity value. The porosity can be calculated using an equation from the Archie's Law [7],

$$
\rho_{f}=\rho_{w} a \psi^{-m} S^{-2}
$$

where; $\rho_{f}$ is the formation resistivity, $\rho_{w}$ is resistivity of the pore-water, $a$ is the tortuosity, $m$ is the cementation factors, $\psi$ is the porosity and $S$ is the fractions of the pore volume that is filled with groundwater. Since $S$ is the fractions value, the highest value for $S$ is 1 . An aquifer is assumed to be fully filled with water (fully saturated), therefore $S$ is equal to 1 [8]. The area that is fully filled with water called the saturated zone.

\subsection{Geological Area}

The study area in Selangor (Figure 1) is formed during the Devonian period and its lithology is the composition of sandstone or metasandstone. The survey area also consists of Calcareous Series which is the oldest rock made up of calcareous, graphitic and argillaceous sediments. All these type of rocks were deposited from shallow marine environment during Permian period. The Earth movements caused the rocks to metamorphose into limestone, quartzite, quartzite-conglomerate, schist, phyllite and shale.

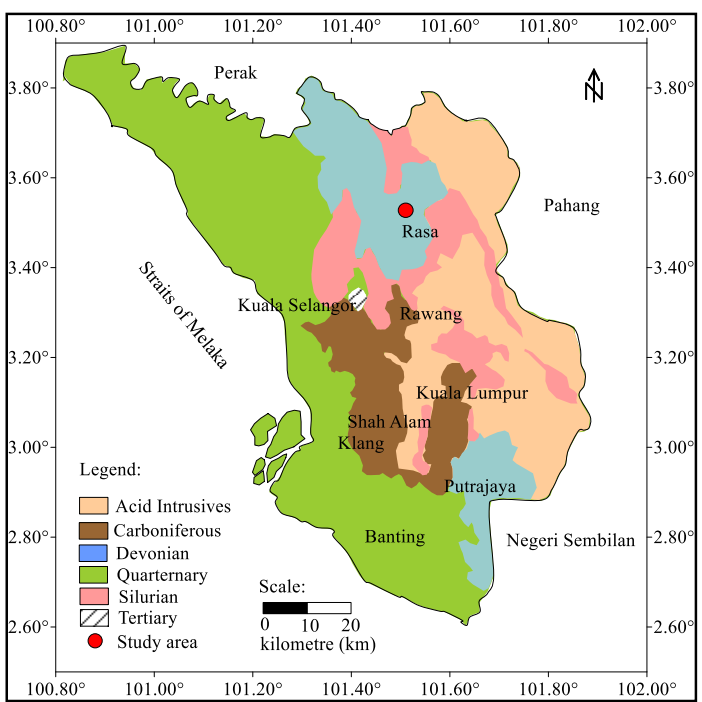

Figure 1 Geological map of Selangor with the location of the study area [9] 
Then, Kelantan (Figure 2) is located on the Northeast of Peninsular Malaysia. The study area is situated between Triassic Kemahang granite and Permian Taku Schist boundary. Kemahang granite is bound to Taku Schist on North and East part, whereas the Kemahang granite is bound to Taku Schist with shale on the South. Kemahang granite is classified as Triassic I-type granite [10]. Meanwhile, Permian Taku Schist has undergone metamorphism, which produced crystalline, completely schistose and predominantly mica-garnet schists and quartz-mica-garnet schists in which bands of amphibole schist and narrower bands of quartz and serpentine were formed. The contact or boundary between Kemahang Granite and Taku Schist is asymmetrical and could be a simple unconformity [11].

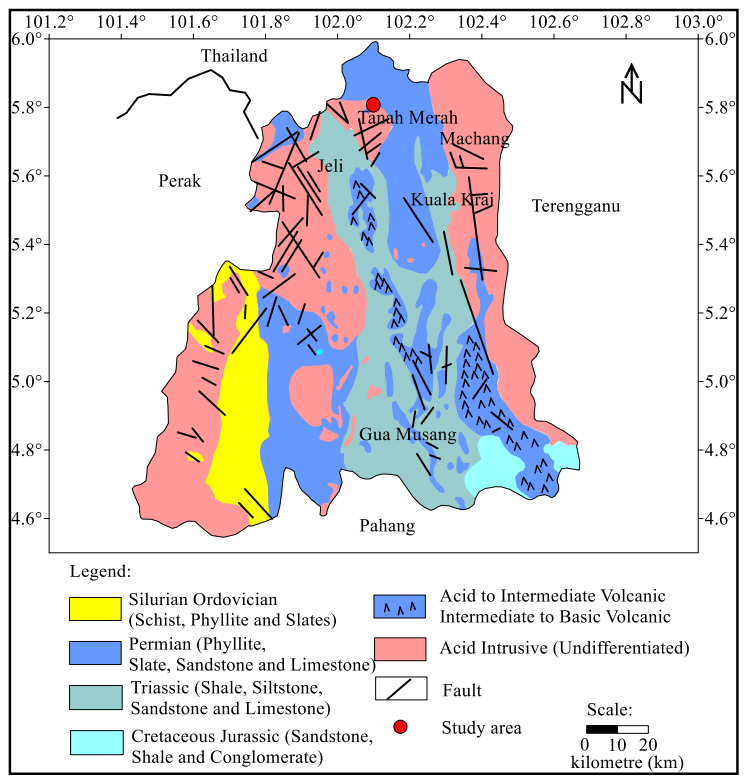

Figure 2 Geological map of Kelantan with the location of the study area [9]

\subsection{Study Area}

The surveys were conducted in Selangor and Kelantan. The survey lines in Selangor (Figure 3) were conducted in a residential area and near to a lake. The total length for both lines (SEL 1 and SEL2) is $200 \mathrm{~m}$ with $5 \mathrm{~m}$ electrode spacing.

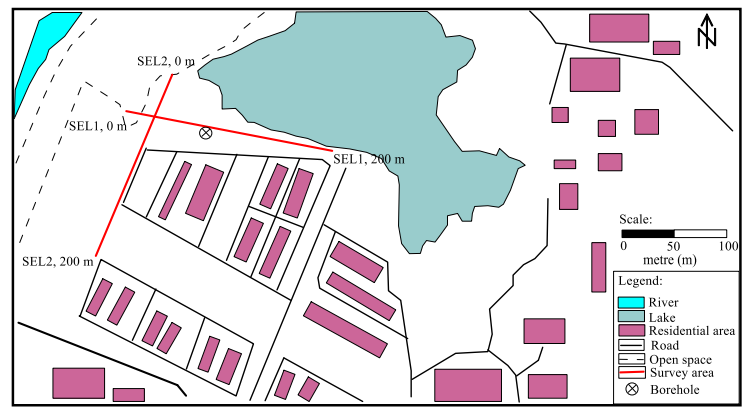

Figure 3 Location of the survey lines and borehole conducted in Selangor [12]
The survey lines in Kelantan (Figure 4) were conducted in an agriculture farm area and surrounded with some bushes. The total length for both lines (KEL 1 and KEL2) at this area is longer than the survey lines in Selangor which is $400 \mathrm{~m}$ with $10 \mathrm{~m}$ electrode spacing.

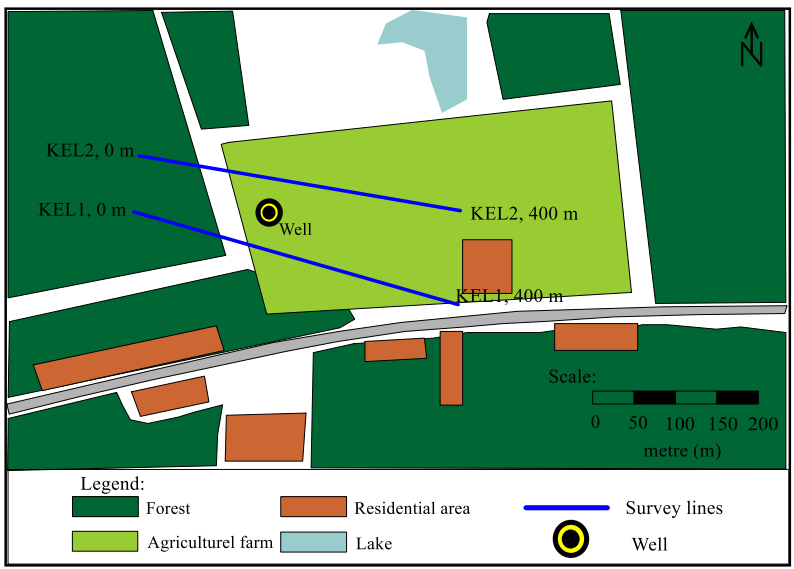

Figure 4 The location of the survey lines and a well drilled in Kelantan [13]

\subsection{METHODOLOGY}

Two resistivity survey lines were carried out in each of the study area. Pole-dipole array was employed for all lines using ABEM SAS4000 system and a multi electrode selector that is connected to multicore cables, a remote cable and none polarized electrodes. A borehole was drilled at a distance of $85 \mathrm{~m}$ on the line 1 (SEL1) in Selangor whereas in Kelantan, a borehole was drilled between line 1 (KEL1) and line 2 (KEL2).

The processing of the 2-D resistivity raw data was done using Res2Dinv software. The resistivity values from 2-D resistivity inversion model were used to calculate the porosity percentage of the subsurface from the Archies's Law. The porosity percentage is automatically calculated using Microsoft Excel software via a template prepared beforehand with equations filled in for quick and accurate calculations.

$$
\rho_{f}=\rho_{w} a \Psi^{-m} S^{-2}
$$

The value of $\rho$ and $\rho_{w}$ are taken from 2-D resistivity results while values of tortuosity, a and cementation factors, $m$ are constant value taken from Table 1. The value of $a$ and $m$ are chosen according to their geological information such as age or rock type. For example, $a$ and $m$ values for SEL 1 and SEL2 are 0.62 and 1.95 respectively. The values were chosen due to their formation age that formed during Devonian period which is in Paleozoic age. Then, the value of $S$ is assumed to 1 as fully saturated. The porosity percentages were then divided as $<20 \%$ or $>20 \%$ to look either it can be productive aquifer or not. 
Table 1 The suggested value for constant $a$ and $m$ to use in Archie's formula when the lithology of the rock is known (Keller, 1987)

\begin{tabular}{|c|c|c|}
\hline Description of rock & a & m \\
\hline $\begin{array}{l}\text { Weakly cemented detrital rocks, such as sand, sandstone and some limestones with a porosity range from } 25 \\
\text { to } 45 \% \text {, usually Tertiary in age }\end{array}$ & 0.88 & 1.37 \\
\hline $\begin{array}{l}\text { Moderately well-cemented sedimentary rocks, including sandstones and limestones with a porosity range } \\
\text { from } 18 \text { to } 35 \% \text {, usually Mesozoic age }\end{array}$ & 0.62 & 1.72 \\
\hline Well-cemented sedimentary rocks with a porosity range from 5 to $25 \%$, usually Paleozoic in age & 0.62 & 1.95 \\
\hline Highly porous volcanic rocks, such as tuff, aa and pahoehoe, with porosity in range 20 to $80 \%$ & 3.5 & 1.44 \\
\hline Rocks with less than $4 \%$ porosity, including dense igneous rocks and metamorphosed sedimentary rocks & 1.4 & 1.58 \\
\hline
\end{tabular}

Finally, the 2-D porosity imaging of the subsurface was produced using Surfer8 software. Figure 5 shows the flow chart that sums up the methodology in this study.

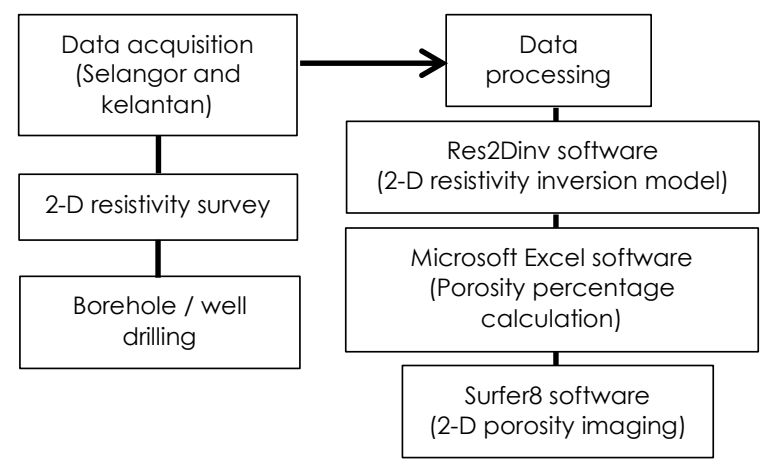

\subsection{RESULTS AND DISCUSSION}

The survey line SEL1 was conducted near a lake whereas SEL2 was perpendicular to SEL1. Figure 6 shows the 2-D resistivity inversion model of SEL 1 which can be divided into two main zones. The first zone is the saturated zone or water bearing rock (1-100 $\Omega \mathrm{m})$ at depth of $10-70 \mathrm{~m}$. The second zone is underlain by competent bedrock with resistivity value of $>400 \Omega \mathrm{m}$ [14].

Generally, water in hard rocks will seep through the fractures within the rock and accumulates to become groundwater. The groundwater is commonly found at deeper depth, but many groundwater in Malaysia is shallow within fracture system [4]. The saturated zone or water bearing rock (1-100 $\Omega \mathrm{m}))$ is suspected to be the aquifer at distance between 75-120 m.

Figure 5 The flow chart for this study

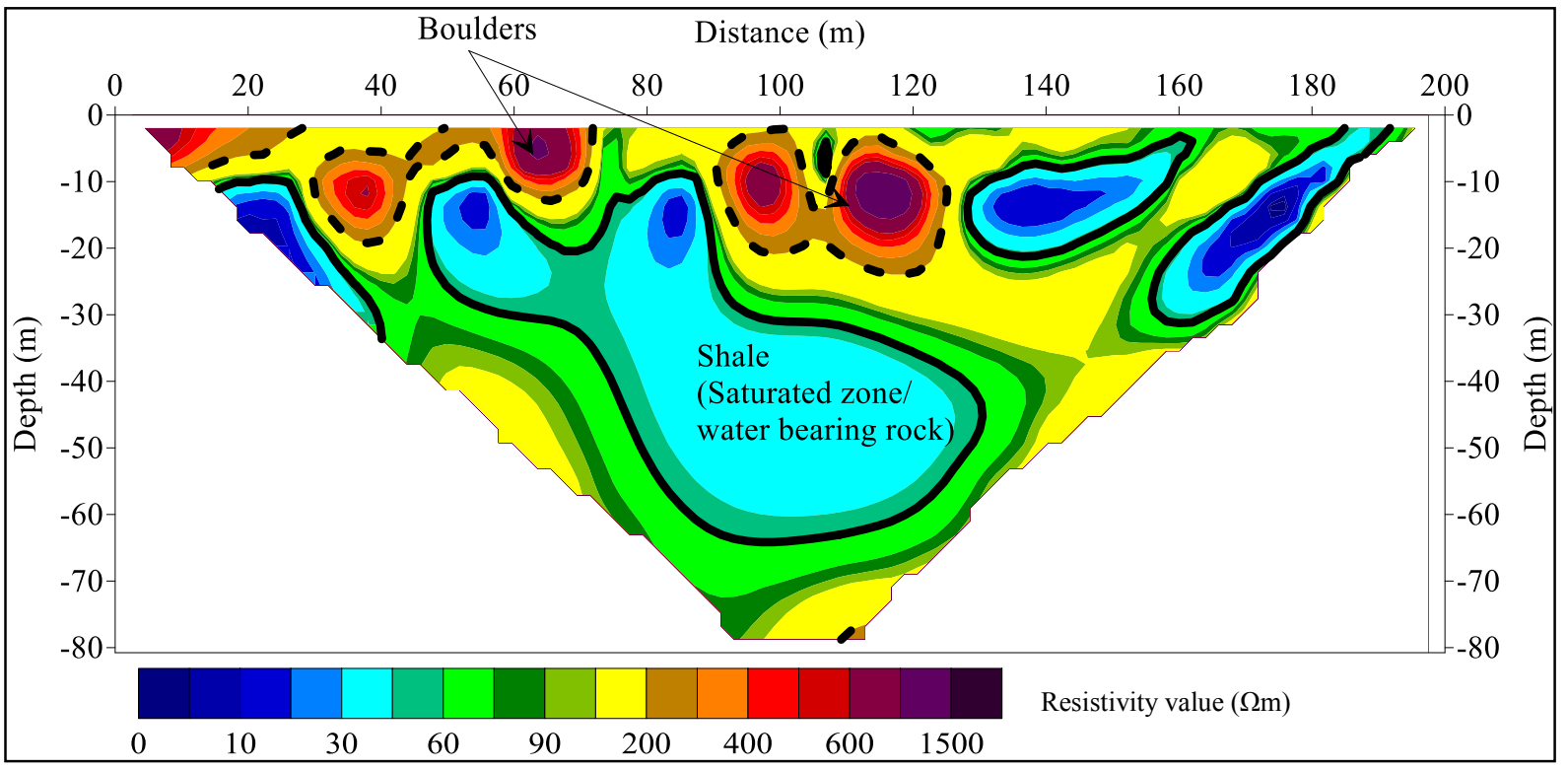

Figure 6 The 2-D resistivity inversion model for survey line SEL 1 
Figure 7 shows the 2-D resistivity inversion model of SEL 1 correlated with the borehole record. The low resistivity zone (1-100 $\Omega \mathrm{m})$ in the inversion model was interpreted as saturated zone and the borehole record agrees with the aquifer zone at the depth of
15-50 m. Both 2-D resistivity inversion model and borehole data show that the aquifer zone is located $15-50 \mathrm{~m}$ depth. The borehole data proved that the saturated zone is an aquifer. Shale acts as waterbearing rock and becoming an aquifer.

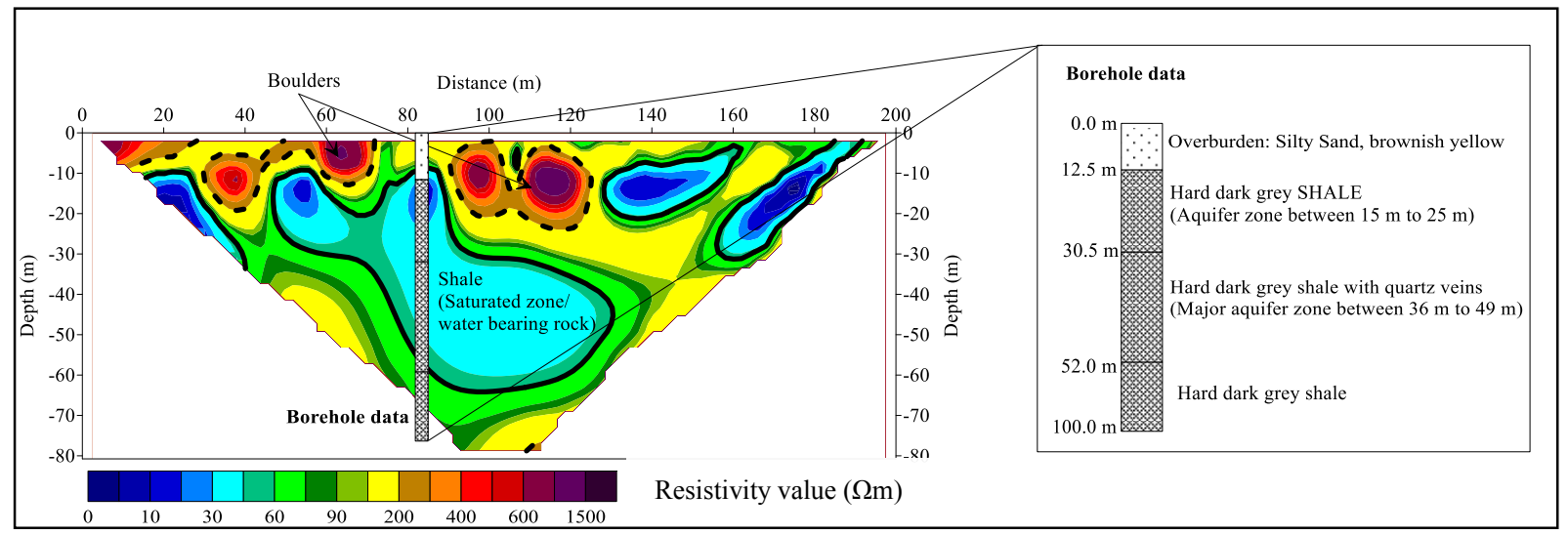

Figure 7 The correlation of 2-D resistivity inversion model of line SEL1 with borehole record at distance $85 \mathrm{~m}$

The saturated zone or water bearing rock (1-100 $\Omega \mathrm{m}$ ) in SEL2 (Figure 8) is located at 15-50 $\mathrm{m}$ depth. From the borehole record, the bedrock found is hard dark grey shale. Thus, the $>400 \Omega$ m of resisitivity value was interpreted as shale bedrock, and a boulder of shale found between two saturated zones at distance between 80-100 $\mathrm{m}$ in line SEL2 indicates the presence of fractures in the rock. The fractured zone can be interpreted as the saturated zone located in between or below the high resistivity value of bedrock [12].
Moreover, the low resistivity values zone (1-100 $\Omega \mathrm{m}$ ) between the boulders were suspected as saturated zone or water bearing rock since the scale of the resistivity value used in this zone is similar as SEL 1. The saturated zone or water bearing rock is formed due to fractures in the rock which allow water to flow through it and trap the water inside. The resistivity value of the rock is lower with greater fracturing [4]. Thus, the saturated zone could be a potential aquifer.

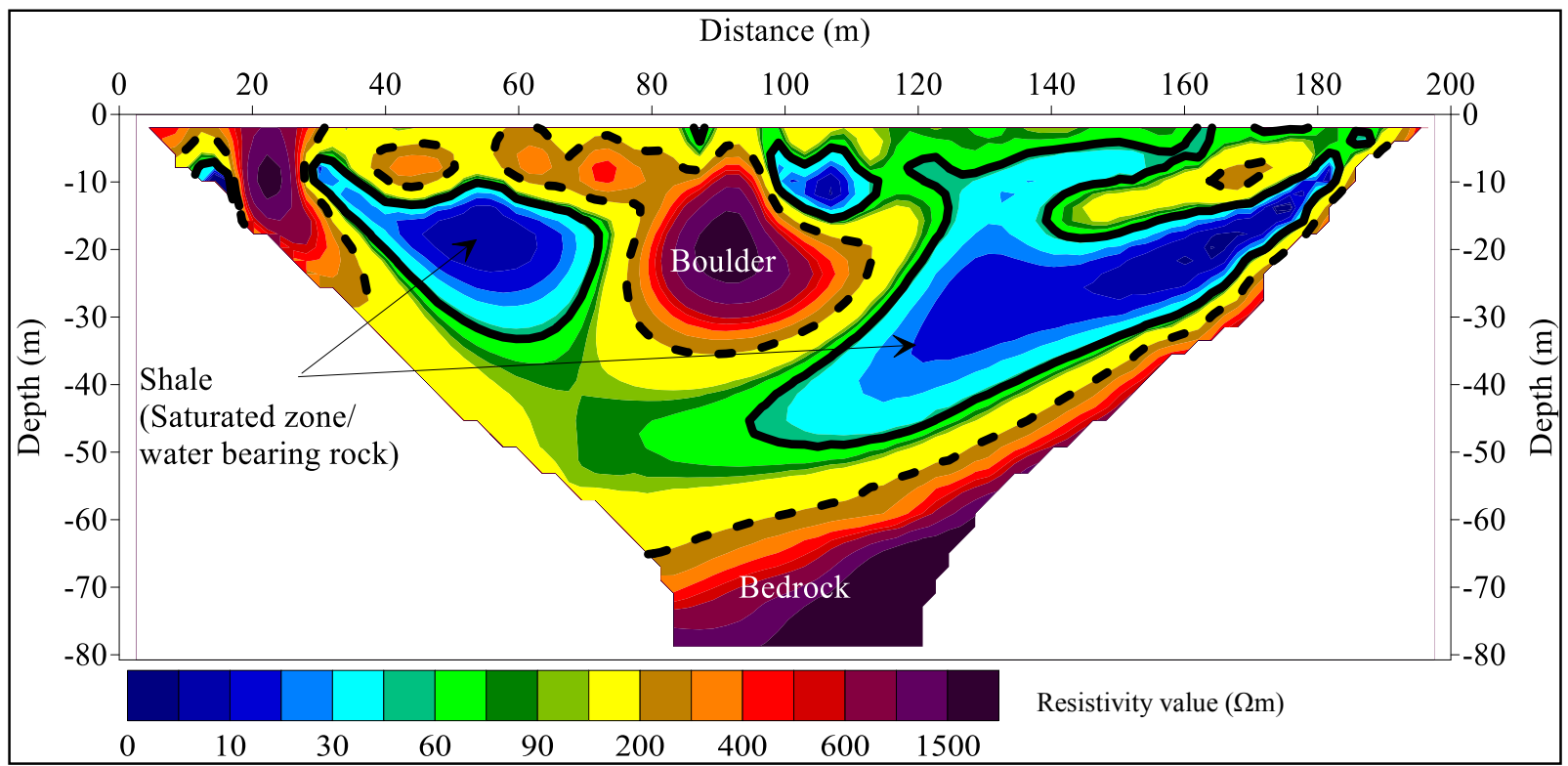

Figure 8 The 2-D resistivity inversion model for survey line SEL2

Porosity determination is applied in measuring the ability of the rock materials to hold and store water. The resistivity values obtained from the 2-D resistivity results was used to calculate percentage of porosity using the Archie's law equation. Then, the 2-D porosity imaging was contoured based on the porosity values 
for a clearer image. This porosity imaging will be divided into two parts; $<20 \%$ or $>20 \%$. This is because a productive sedimentary aquifer should contain at least $20 \%$ of porosity, [8] where porosity of $>20 \%$ is considered as high porosity [15]. The porosity of the subsurface materials was determined to verify the aquifer identification at the study area. Figures 9 and 10 are the 2-D porosity imaging of SEL1 and SEL2 respectively, where the saturated zone or water bearing rock with resistivity value of 1-100 $\Omega \mathrm{m}$ (aquifer zone) has a porosity of $>20 \%$ while the other part (>100 $\Omega \mathrm{m}$ ) has porosity of $<20 \%$. The greater the pore spaces in the rocks, the greater the amount of water it can hold. The area with $<20 \%$ porosity is a good seal rock as it prevents water from flowing out, trapping water within the rock fractures. All pore spaces or fractures that are filled with water in sediment or rock are saturated. Thus, all the suspected saturated zones in 2$D$ resistivity inversion model should have a high percentage of porosity.

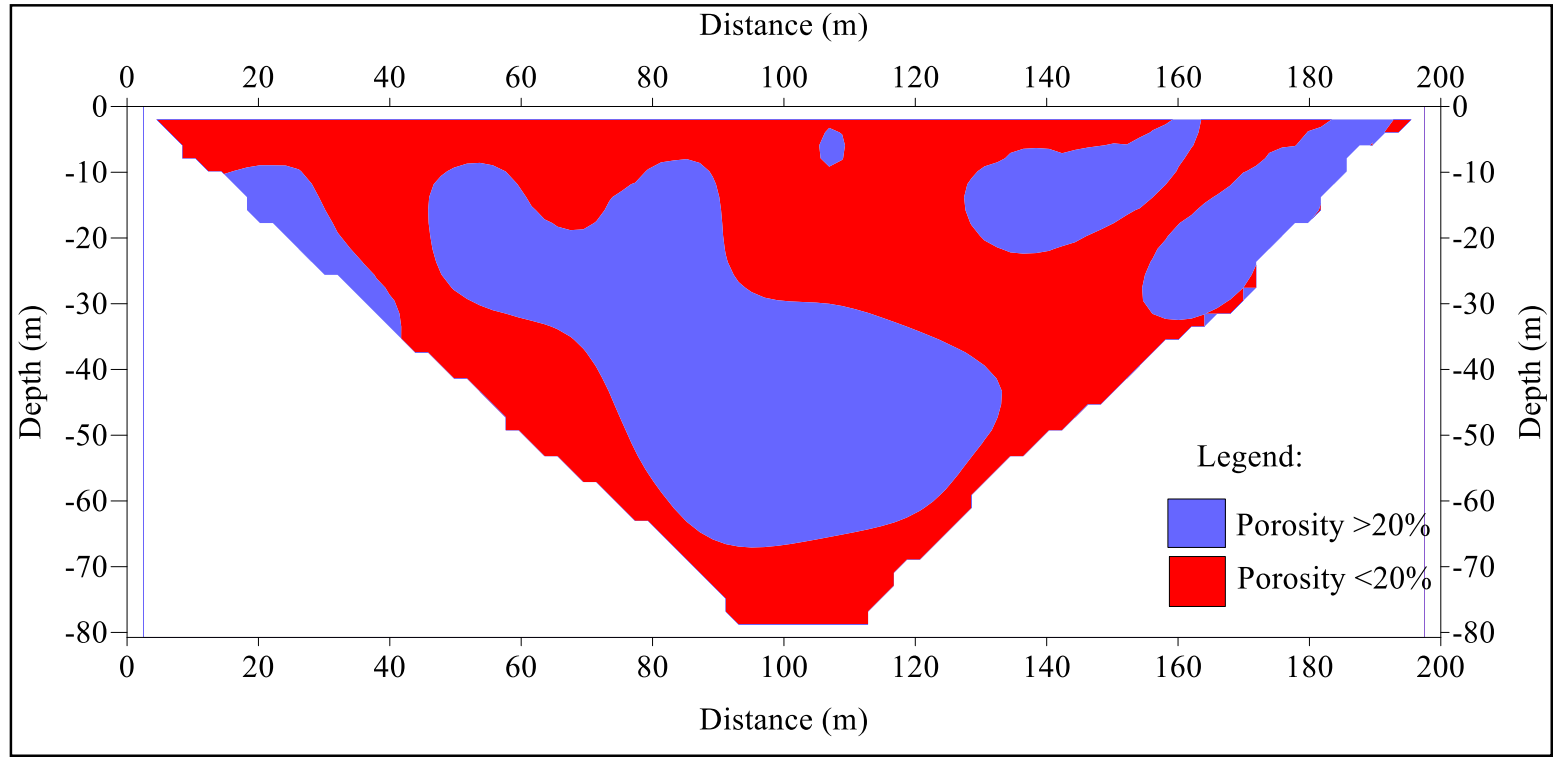

Figure 9 The 2-D porosity imaging of SEL 1

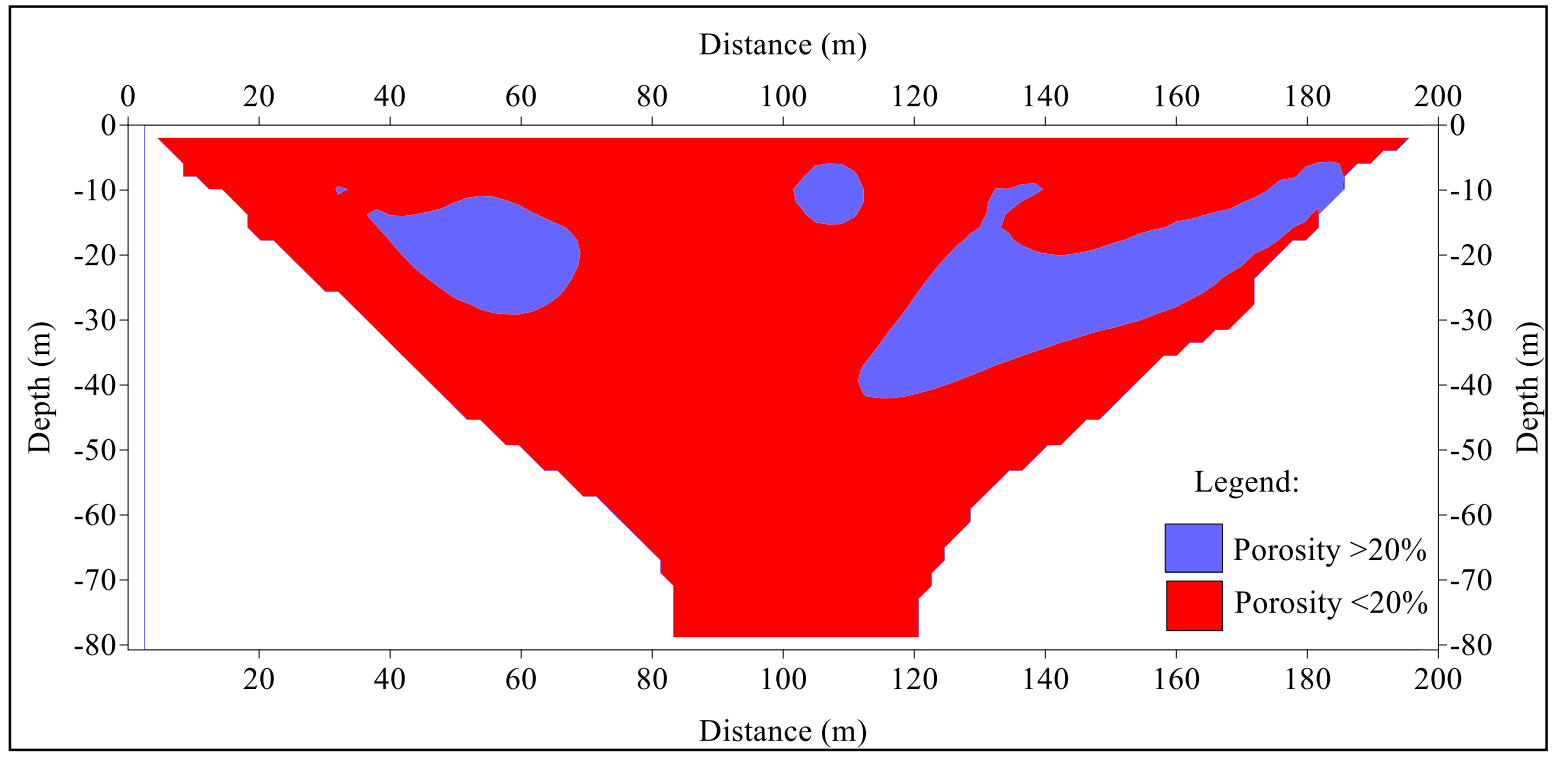

Figure 10 The 2-D porosity imaging of SEL2

The second study area in Kelantan is located between Kemahang Granite and Taku Schist. All 2-D resistivity inversion models in the area can be divided into three different zones as shown in Figure 11 and 12.
The first zone is saturated zone or water bearing rock with resistivity value of 1-100 $\Omega \mathrm{m}$. Resistivity values between $800-3000 \Omega \mathrm{m}$ is the second zone interpreted as sandstone. The third zone is classified as granite 
bedrock (>3000 $\Omega \mathrm{m})$. Ismail found that the saturated zone at an area that made up of granite bedrock has resistivity value of $0-100 \Omega m[12]$.

KEL 1 in Figure 11 shows that the granite bedrock is found at distance from 1-110 $\mathrm{m}$ and 120-400m with moderate resistivity value that was interpreted as sandstone. The depth of sandstone is quite shallow, which is about $40 \mathrm{~m}$ from the surface. A contact zone between the granite bedrock and sandstone was suspected to be a fractured zone at distance of 110 $\mathrm{m}$.

KEL2 in Figure 12 shows exactly the same finding as KEL 1 line, where the granite bedrock is located at distance of $<100 \mathrm{~m}$ from the total length. At distance $110 \mathrm{~m}$ of KEL2 line, a contact zone was found between granite and sandstone. One saturated zone or water bearing rock is spotted in KEL2 line at distance 320-360 $\mathrm{m}$. The fracture and contact zones between sandstone and granite bedrock allow the water to flow and seeps into the rocks and caused the formation of saturated zone or water bearing rock (1$100 \Omega \mathrm{m})$. For example at distance of $110 \mathrm{~m}$ of line KEL2, a small contact zone between granite and sandstone tend to form fractures that transmit and accumulate the water. Nielsen stated that the fractures form an irregular pattern of interconnected or isolated conduits of water [16]. Fractures are called secondary porosity of sandstone that allowed water to accumulate [17]. Thus, the saturated zone has the potential to be an aquifer.

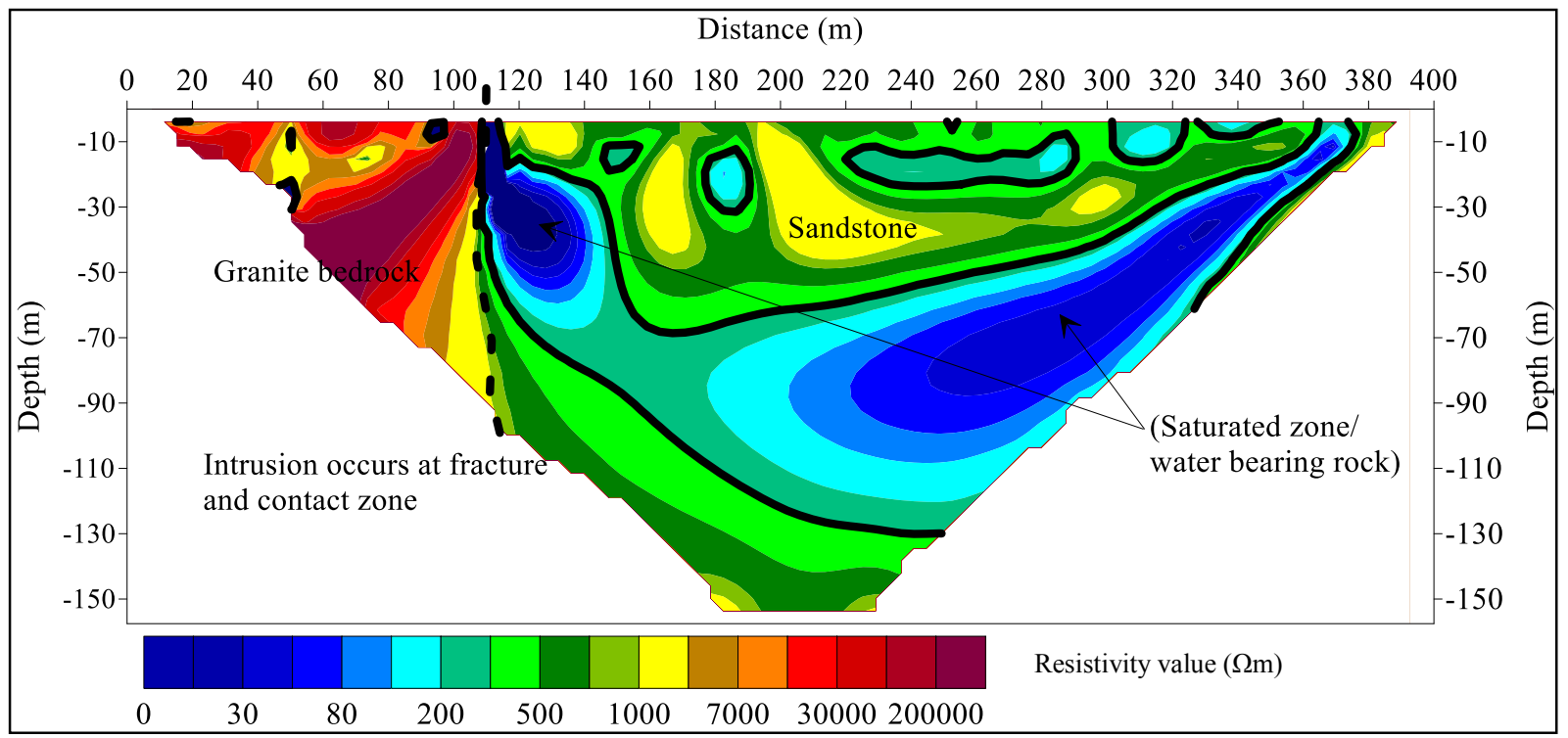

Figure 11 The 2-D resistivity inversion model line KEL 1

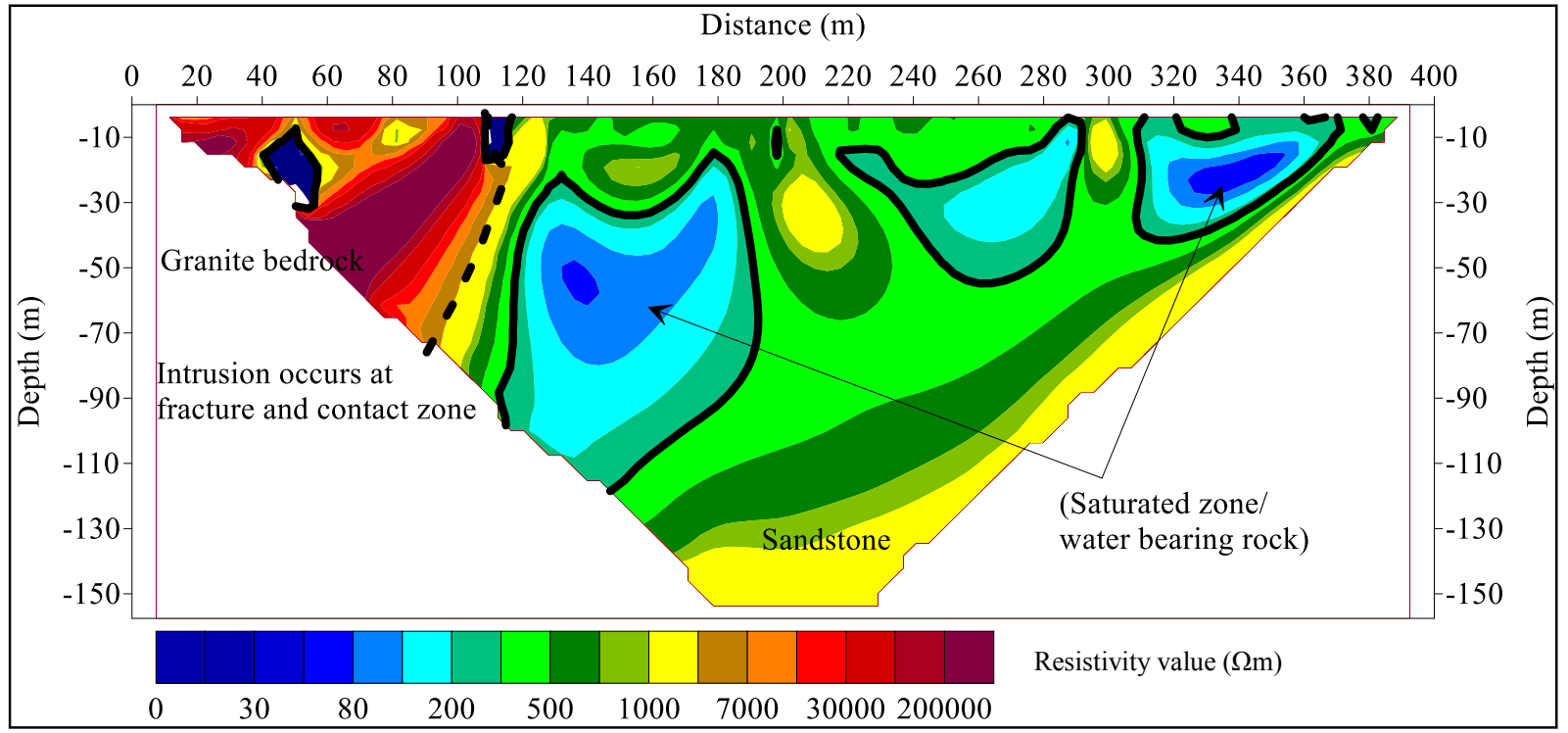

Figure 12 The 2-D resistivity inversion model line KEL2 
Area between lines KEL1 and KEL2 which are known as the contact zones become the main targets for water wells and spring due to the formation of fractures along the zone [18]. The largely connected, closely spaced and multiple fractures may produce a sustainable well yields [19]. The water well was drilled $38 \mathrm{~m}$ away from the nearest point of line KEL2 at distance of $110 \mathrm{~m}$ of the line. According to 2-D resistivity inversion model of lines KEL1 and KEL2, the well drilled location is at the suspected contact zone.
The lithology from the well log data shows different materials which are red clay, red sand and red granite (Figure 13). Red clay is found at top of the subsurface, followed by red sand at depth of $15 \mathrm{~m}$ and granite at depth of $53 \mathrm{~m}$. A few subsurface materials are similar with the interpretations from the 2-D resistivity inversion model and the well log data, where both consist of granite. Red sand may originated from sandstone whereas clay may come from weathered granite bedrock or sandstone.

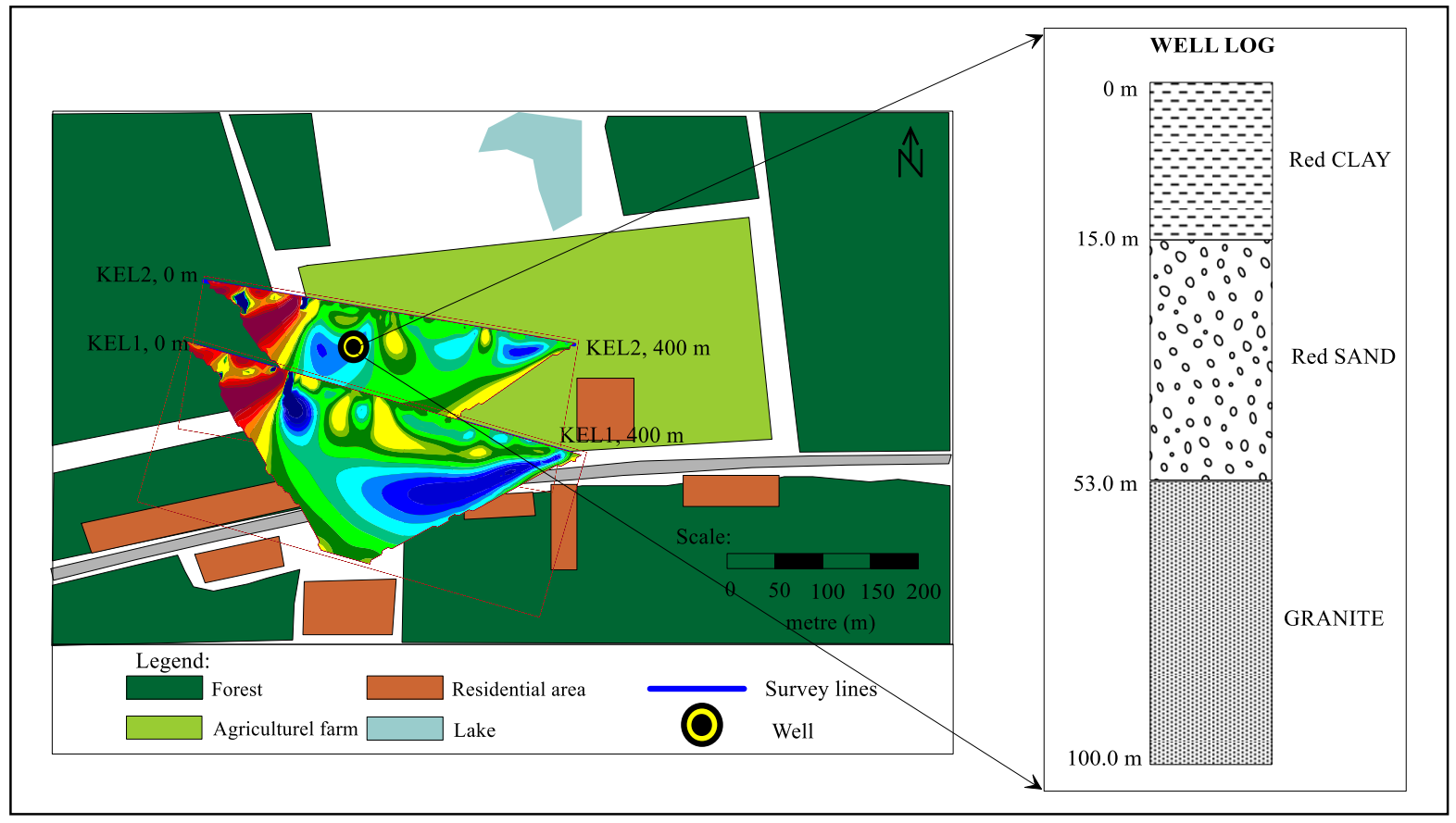

Figure 13 The well log between line KEL1 and KEL2

Clay and sand have a high porosity as the water can store in the pore spaces. Poorly sorted grain sizes increase the pore spaces especially in the sand zone at depth of 15-53 m. Sand does not only produced high porosity but it is also high in permeability which allows water to seep through. Although both materials have high porosity, only sand has a high permeability [15]. It is because clay is composed of fine grains which are close to each other and reduces the empty spaces. The well log shows clay at the top surface to $15 \mathrm{~m}$ depth which acts as a confining layer and traps the water from escaping to the ground surface. Bedrock is found at the bottom part starting from $53 \mathrm{~m}$ depth onwards, preventing water from flowing deeper due to gravity force. The data was validated when a huge amount of water comes out during drilling process due to high pressure of the subsurface as shown in Figure 14.

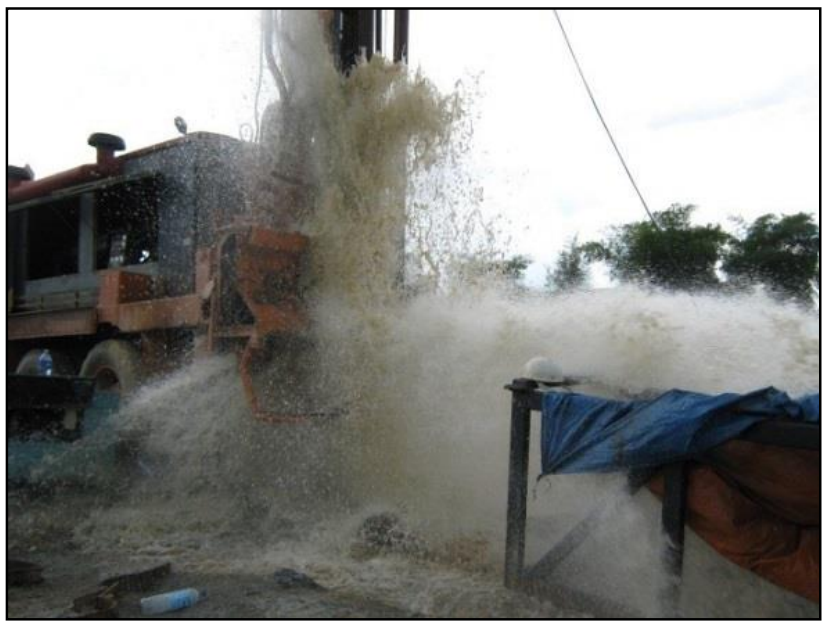

Figure 14 Water comes out during the well drilling process 
Figures 15 and 16 are the 2-D porosity imaging for both survey lines (KEL1 and KEL2) in Kelantan. The porosity imaging show that all saturated zones with 1-100 $\Omega \mathrm{m}$ resistivity value have a porosity of $>20 \%$. The porosity of $>20 \%$ is considered as highly porous [15] due to the pores and rock fractures that may be filled with water. The larger the fractures, the greater the amount of water can be filled in the fractures. Pore size distribution, grain size distribution, void ratio, roughness of mineral particles, fluid salinity or mineralization, degree of weathering, fissure density and interconnectivity and water saturation are factors that affect the hydraulic and electric conductivities. However,for hard rock (granite), the dominant factor is the rock porosity saturated with water [20]. This is because the water in the fissures is controlled by current flow since the minerals in the granite has high resistivity [20].

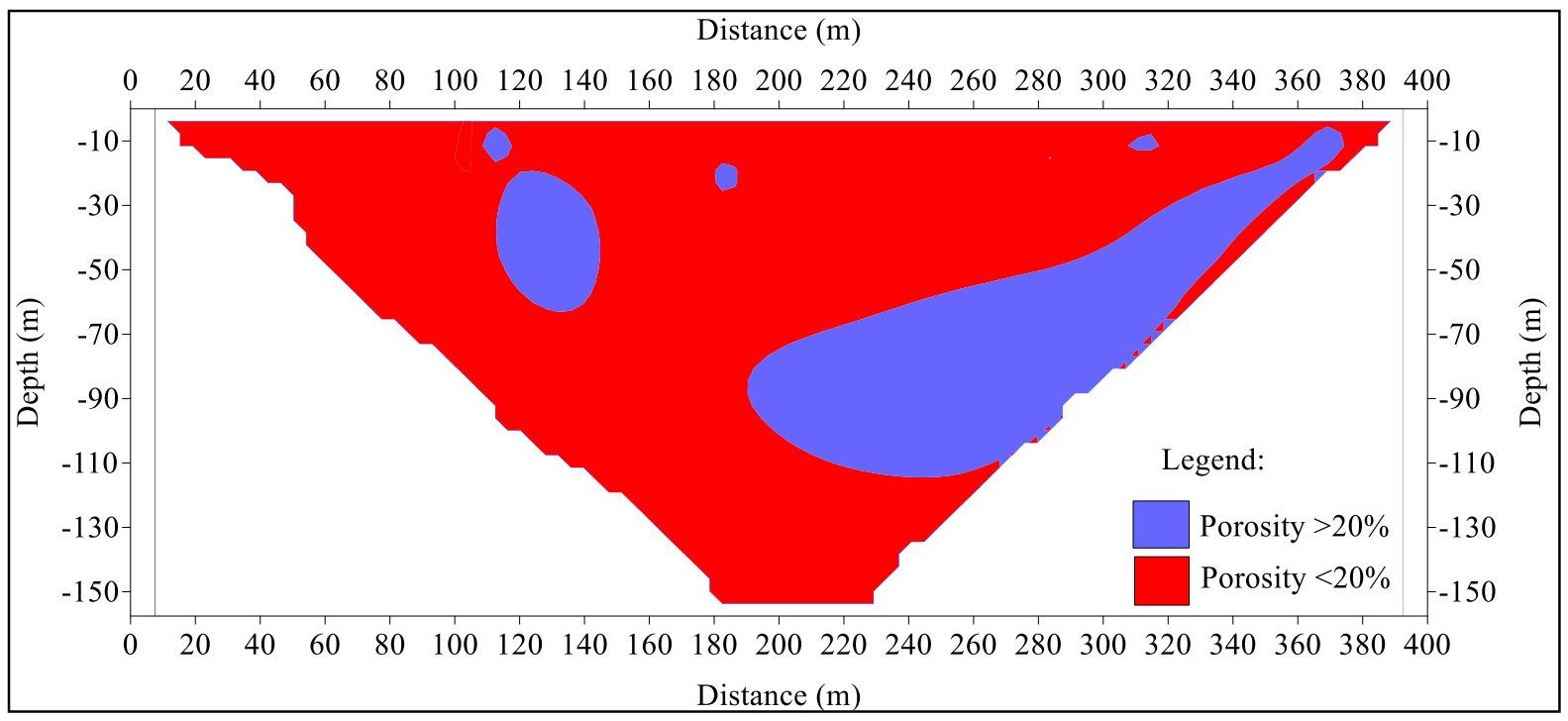

Figure 15 The 2-D porosity imaging of KEL 1

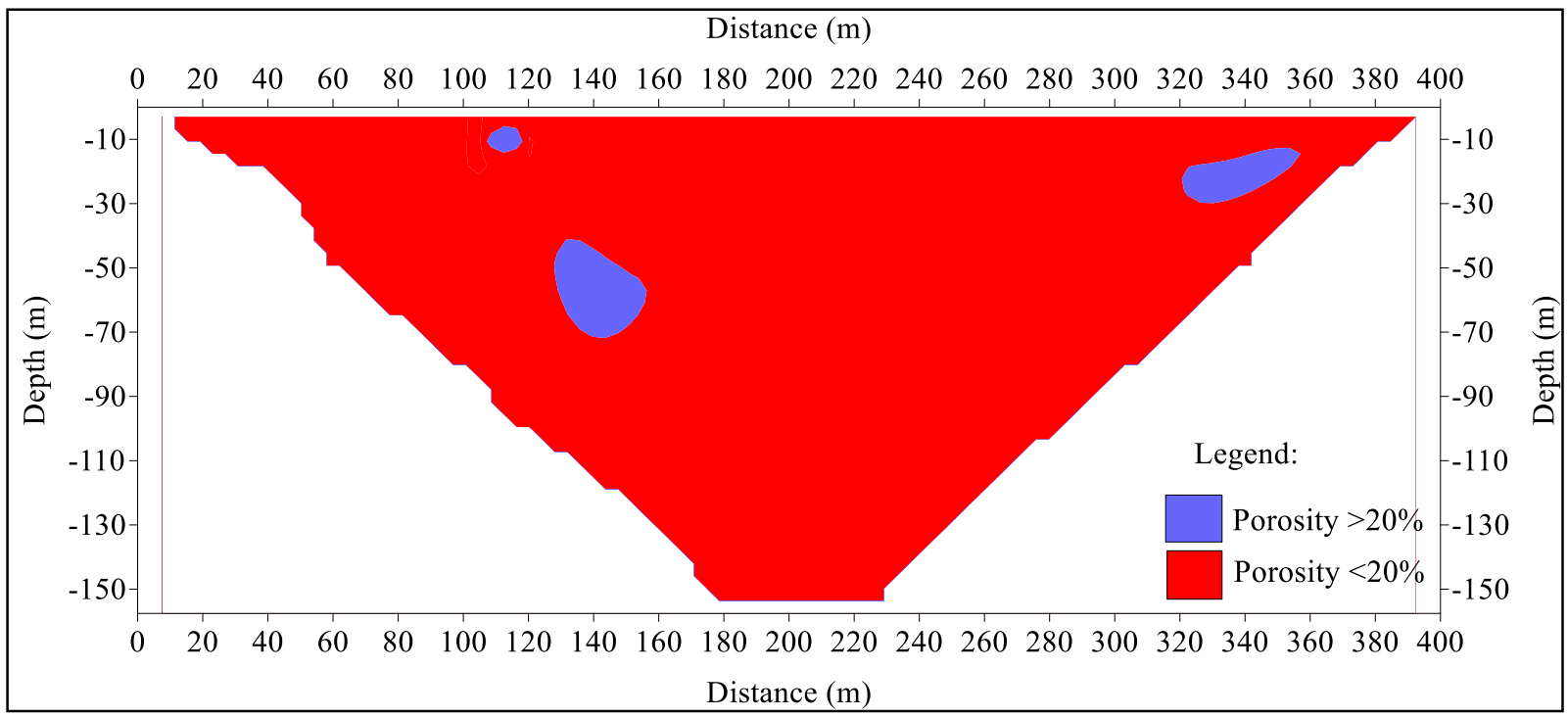

Figure 16 The 2-D porosity imaging of KEL2

\subsection{CONCLUSION}

Good correlation was achieved between 2-D resistivity result and borehole record, where saturated zone in both study areas are concluded and proven to be an aquifer. Verified Archie's law is also applicable in calculating porosity of the subsurface materials since the saturated zone or the aquifer area has porosity of $>20 \%$. 


\section{Acknowledgement}

The authors thanked all the technical staffs of the Geophysics laboratory and postgraduate students, School of Physics, Universiti Sains Malaysia for their assistance during the data acquisition. The authors also would like to express gratitude to USM for providing the Research University Grant (RUI) with the title "Geophysical Application and Approaches in Engineering and Environmental Problems" (1001/PFIZIK/811323).

\section{References}

[1] Reynolds, J. M. 1997. An Introduction to Applied and Environmental Geophysics. John Wiley \& Sons Inc. Chichester.

[2] Lashkaripour, G. R., Ghafoori, M. and Dehghani, A. 2005. Electrical Resistivity Survey for Predicting Samsor Aquifer Properties, Southeast Iran. Geophysical Research Abstracts, 7: 01999, 2005. European Geosciences Union 2005.

[3] Khaki, M., Yusoff, I. and Islami, N. 2014. Investigation of the Groundwater Aquifer by Resistivity Method at Dengkil, Malaysia. The 12th Asia Pacific Physics Conference. Proceeding paper. 1206.

[4] Saad, R., Nordin, M. N. M. and Mohamad, E. T. 2012. Groundwater Detection in Alluvium Using 2-D Electrical Resistivity Tomography (ERT). Electronic Journal of Geotechnical Engineering. 17(Bund D): 369-376.

[5] Nordiana, M. M., Rosali, S., Mokhtar, S. M., Nawawi, N. M. M. and Azwin, I. N. 2012. Imaging Subsurface Characterization at Bukit Bunuh using 2D Resistivity Method: The Effectiveness of Enhancing Horizontal Resolution (EHR) Technique. Int. J. Environ. Sci. Develop. 3(6): 569-573.

[6] Denchik, N. and Chapellier, D. 2005. 3D Electrical Resistivity Monitoring during Rainfalls. Proceeding of the Paper Presented at the 3rd Swiss Geoscience Meeting.

[7] Soupius, P. M., Kouli, M., Vallianatos, F., Vafidis, A. and Stavroulakis, G. 2007. Estimation of Equifer Hydraulic
Parameters from Surficial Geophysical Methods: A Case Study of Keritis Basin in Chania (Crete-Greece). Journal of Hydrology. 338:122-131.

[8] Tsiboah, T. 2002. 2D Resistivity and Time-Domain EM in Aquifer Mapping: A Case Study, North of Lake Naivasha, Kenya. Msc Thesis, International Insitute for Geo-information Science and Earth Observation, 66.

[9] Geological Map of Peninsular Malaysia, Based On 8th Edition Geological Map. 1985. Minerals and Geoscience Department, Malaysia.

[10] The Malaysian and Thai Working Groups 2006. Geology of the Batu Melintang-Sungai Kolok Transcent Area along the Malaysia-Thailand Border. A Joint Project Carried out by Minerals and Geoscience Department Malaysia and Department of Mineral Resources, Thailand. The MalaysiaThailand Border Joint Geological Survey Committee (MTJGSC). 20-30.

[11] Macdonald, S. 1967. Geology and Mineral Resources of North Kelantan and North Terengganu. Geology Survey Malaysia Memoir. 10: 8-18, 87-88.

[12] Ismail, N. E. H. 2011. Groundwater Findings Using 2-D Resistivity Imaging Method. Msc Thesis, Universiti Sains Malaysia.

[13] Google Earth. 2016.

[14] Keller, G. V. and Frischknecht, F. C. 1996. Electrical Methods in Geophysical Prospecting. Pergamon Press Inc., Oxford.

[15] Subramanya, K. 2013. Engineering Hydrology Fourth Edition. McGraw Hill Education (India) Private Limited, New Delhi.

[16] Nielsen, K.A. 2007. Fractured Aquifer-Formation Evaluation by Well Testing. Trafford Publishing, Canada. 7-15.

[17] Yadav, G. S. 1995. Relating Hydraulic and Geoelectric Parameters of the Jayant Aquifer, India. Journal of Hydrology. 167: 23-38.

[18] Monroe, J. S., Wicander, R. and Hazlett, R. W. 2007. Physical Geology: Exploring the Earth. $6^{\text {th }}$ edition. Belmont, Brooks/Cole Pub Co.

[19] Kasenow, M. 2006. Aquifer Test Data: Analysis and Evaluation. Water Resoures Publication, LLC, United State of America. 2-25.

[20] Chandra, S., Ahmed, S., Ram, A. and Dewandel, B. 2008. Estimation of Hard Rock Aquifers Hydraulic Conductivity from Geoelectrical Measurements: A Theoretical Development with Filled Application. Journal of Hydrology. $357,218-277$. 